\subsection{This Regional Master Plan}

WEDO/EcoPeace Middle East assigned Royal HaskoningDHV on the 27th of August 2012 to develop national NGO Master Plans for sustainable development of the Jordan Valley for Jordan and Palestine, and one Regional Master Plan for the Jordan Valley, located between the Sea of Galilee and the Dead Sea. WEDO/EcoPeace view this final Master Plan as an advocacy tool to engage with national stakeholders and the international community for the full or partial adoption of the proposed interventions.

The future scenarios and strategic objectives for the Jordan Valley Master Plan presented in this report reflect the vision of WEDO/EcoPeace Middle East and do not necessarily reflect the opinion of the European Union or the individual consultants and their sub-consultants.

This Regional NGO Master Plan describes the current land and water-related issues in the Jordan Valley, and the projections in the valley for the years 2025 and 2050. It presents the major challenges in the valley towards creating sustainable development conditions, including environmental flows provided through natural resources a healthy eco-system, equitable sharing of water resources, and a list of prioritized interventions that will restore the valley's environmental and ecological values within a realistic financial and economic framework. The Jordan Valley is part of the wider Jordan Basin, which includes catchment areas in Lebanon and Syria as well. The upper part of the Jordan River Basin is connected to the Lower part of the Jordan River Basin through Sea of Galilee and the Yarmouk River. This study does not address analysis of the wider Jordan River Basin as a whole, but assumes the hydrological characteristics of the Sea of Galilee and the Yarmouk River as boundary conditions for this study.

An extensive baseline report of the trans-boundary Jordan Valley has been prepared by the Consultant in March 2014, which provides the base for this NGO Master Plan.

\subsection{The Consultants}

Royal HaskoningDHV B.V. is WEDO/EcoPeace's main contractor for this study, and has established sub-contracts with CORE Associates in Palestine, MASAR Center from Jordan and DHVMED from Israel. Key experts from these organizations form the core study team, headed by DHV's project manager. The study team represents an excellent track record in the areas of development of river basin master plans around the world, as well as in water and environmental management projects in Jordan, Israel and Palestine. They have provided a wide range of services, from strategy and policy development and feasibility studies to designs and construction supervision in the Middle East and in different river basins around the world.

RHDHV BV from the Netherlands is part of Royal HaskoningDHV, which is one of the largest independent consultancy groups, employing currently around 8,000 employees world-wide. The firm is a merger between DHV Group and Royal Haskoning Group established on the 1st of July 2012. DHV was founded in 1917 and has gained a world-wide reputation from many projects in a wide range of sectors implemented in more than 70 countries, including river basin and water resources management. Royal HaskoningDHV is registered with the major Financial Institutions and International Agencies, and regularly carries out projects financed by them. See also www. royalhaskoningdhv.com.

CORE Associates is a specialized provider of high-end professional services in Economic and Trade Policy, International Trade, Planning and Business Development Services with its headquarters in Ramallah. CORE provides timely, pragmatic and cost-efficient advice and training in the context of economic and trade policy and negotiations, the formulation and implementation of national policy, and private sector development. CORE's clients include 


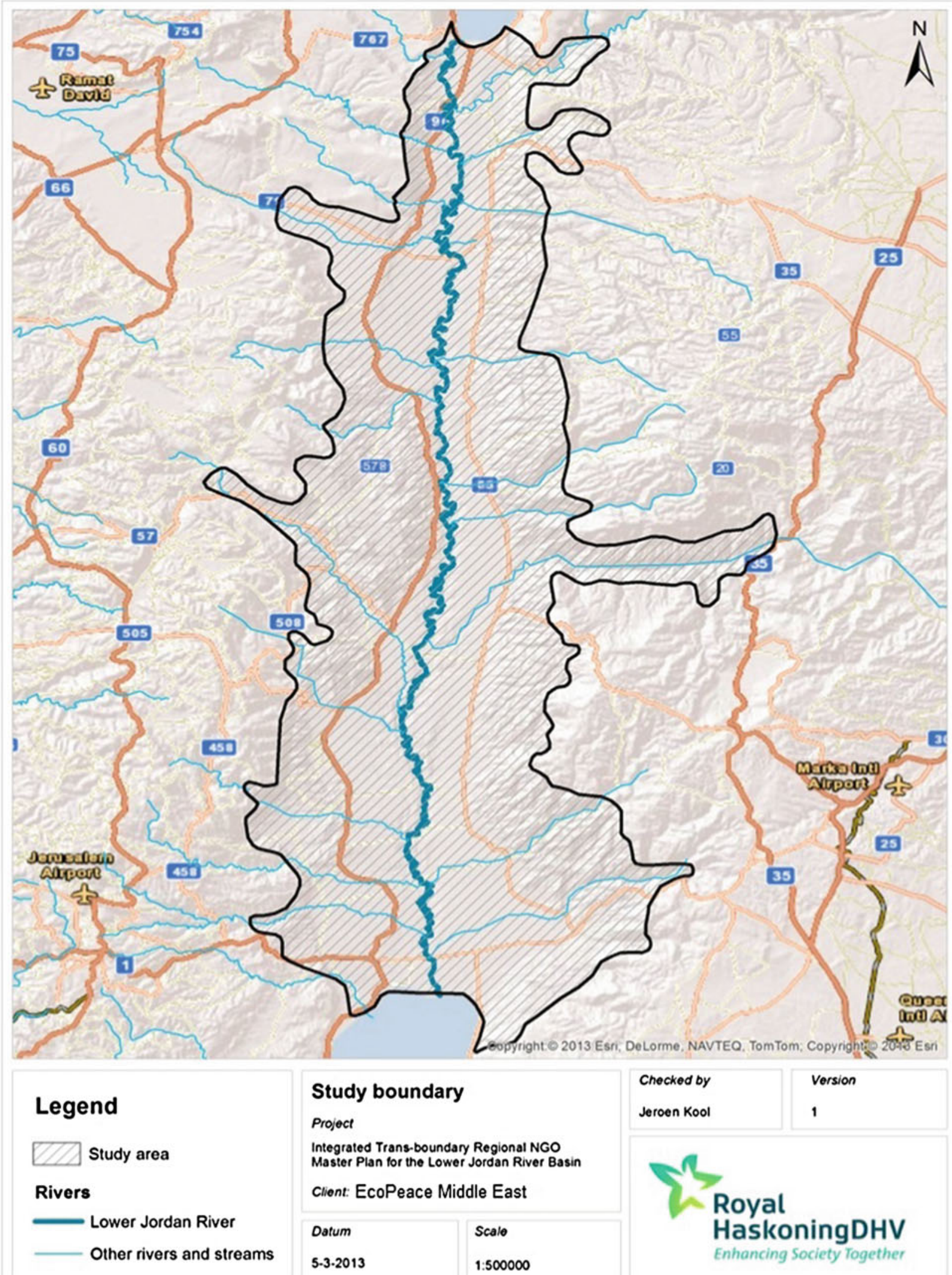

Fig. 1.1 Jordan Valley 
governments, international governmental organizations, as well as NGOs, trade associations, and private businesses. See wWw.core.ps.

MASAR has been established since 1994 as a regional non-government, not-for-profit organization focusing on training projects involving about 12 countries from the MENA region and Europe. MASAR implemented projects in the fields of environment, democracy education, peace and conflict resolution, human rights, gender, interfaith dialogue, youth employment and entrepreneurship. Besides projects in these fields, Masar has also been engaged in providing consulting and expertise to local, regional, and international beneficiaries on matters related to Euro-Med cooperation. See also www.masarcenter.org.

DHVMED was founded in Israel in 1996 as a subsidiary of DHV Group. The company provides consulting engineering services in water, environment, and related infrastructure and counts 30 professional staff. DHV MED specialized in master planning and overall engineering from concept and feasibility studies all the way to general and detailed design. The company provides consulting and design work in WTP (water treatment plants), WWTP (wastewater treatment plants), river basin management, air emission treatment, alternative energy, solid waste management, polluted soil treatment, and more to both the industrial and public sectors. See also www.dhvmed.com (Fig. 1.1).

\section{EcoPeace Staff}

JORDAN

Munqeth Mehyar

Mrs. Yana Abu Taleb

Adnan Budieri

Mrs. Nancy Haddaden

Eshak Al-Guza'a

PALESTINE

Dr. Nader Khateeb

Mrs. Samiramis Kutlo

Nassar Abu Jalal

Marina Djernaes

ISRAEL

Gidon Bromberg

Mrs. Elizabeth Ya'ari

Uri Ginot

\author{
EcoPeace Amman \\ EcoPeace Amman \\ EcoPeace Amman \\ EcoPeace Amman \\ EcoPeace Amman
}

WEDO/EcoPeace Bethlehem

WEDO/EcoPeace Bethlehem

WEDO/EcoPeace Bethlehem

WEDO/EcoPeace Regional

\subsection{The Project Team}

This technical analysis for this Master Plan has been performed by an international team of renowned Jordanian, Palestinian, Israeli and Dutch experts, who have co-operated with the staff of WEDO/EcoPeace to prepare this Regional NGO Master Plan for the Jordan Valley as presented in this report.

\section{Consultant's Team}

KOOL, Jeroen, Project Manager

Al KHATIB, Saad, Economist

AL MASRI, Dr. Mohammad, GIS Expert

AL SHEIKH, Banan, Environmental Expert

BAMYA, Saeb, Geo-political Expert and Palestinian Team Leader

Bany Hany, Lobna, Agricultural Expert

DE GROOT, Mark, Pollution Control Expert

ELRON, Eldad, Ecological Expert and Israeli Team Leader HARTVELD, Dr. Aard, Sociologist

HUNTJENS, Dr. Patrick, Governance Expert

JAYYOUSI, Anan, Water Management Expert

KAPLAN, Moti, Land Use Expert

KWAKKEL, Jeroen, Information Management Support

SAFIER, Gilad, Water Modeling Expert

SHARIF, Dr. Walid, archeological Expert

TALOZI, Dr. Samer, Water Expert and Jordanian Team Leader, Jordan University of Science and Technology

\author{
Director Jordan \\ Assistant Director Projects \\ Assistant Director Amman \\ Assistant Projects Manager \\ Assistant Project Coordinator
}

Director Palestine

PR officer EcoPeace Bethlehem

LJR project director

Executive Operations Officer
EcoPeace Tel Aviv

EcoPeace Tel Aviv

EcoPeace Tel Aviv
Director Israel

Israel Project coordinator

Government Relations 
Open Access This chapter is distributed under the terms of the Creative Commons Attribution 4.0 International License (http://creativecommons. org/licenses/by/4.0/), which permits use, duplication, adaptation, distribution and reproduction in any medium or format, as long as you give appropriate credit to the original author(s) and the source, a link is provided to the Creative Commons license and any changes made are indicated.
The images or other third party material in this chapter are included in the work's Creative Commons license, unless indicated otherwise in the credit line; if such material is not included in the work's Creative Commons license and the respective action is not permitted by statutory regulation, users will need to obtain permission from the license holder to duplicate, adapt or reproduce the material. 